\title{
Perbandingan Kinerja Simpang dengan Pengaturan Petugas Tidak Resmi, Tanpa Pengaturan, dan Pengaturan Sinyal (Studi Kasus Simpang Kronggahan Sleman)
}

\author{
Prima J. Romadhona dan Aprizal Yuliansyah \\ Program Studi Teknik Sipil, Fakultas Teknik Sipil dan Perencanaan, Universitas Islam Indonesia \\ E-mail : primadhona@uii.ac.id
}

\begin{abstract}
ABSTRAK
Pada simpang tidak bersinyal dengan arus lalu lintas yang cukup tinggi sering dijumpai petugas tidak resmi yang berasal dari warga sekitar persimpangan.Keberadaan petugas tidak resmi sebagai pengatur dapat mempengaruhi tingkat pelayanan pada simpang tersebut. Pada penelitian ini bertujuan untuk mengetahui perbandingan kinerja simpang dengan pengaturan petugas tidak resmi, tanpa pengaturan, dan pengaturan menggunakan sinyal di simpang Kronggahan Sleman. Data primer didapatkan dari hasil survei arus lalu lintas, geometri, kecepatan, dan driving behaviour. Analisis perhitungan waktu siklus simpang didasarkan pada Direktorat Jenderal Bina Marga (MKJI 1997), tingkat pelayanan mengacu pada Peraturan Menteri Perhubungan nomor PM 96 Tahun 2015, dan pemodelan menggunakan program VISSIM. Hasil pemodelan VISSIMdidapatkan tundaan rata-rata untuk kondisi simpang tanpa pengaturan adalah 28,19 detik, pengaturan sinyal 35,73 detik, dan pengaturan petugas tidak resmi 7,02 detik. Tingkat pelayanan simpang dengan pengaturan petugas tidak resmi lebih baik yakni B dibandingan dengan kondisi tanpa pengaturan dan pengaturan sinyal (D).Dilihat dari pengaturan PTR yang tidak terdapat waktu hilang (LTI), dan juga dapat menyesuaikan dengan keadaan lalu lintas yang terjadi, sehingga pengaturan PTR memiliki waktu tundaan yang lebih rendah dibandingkan dengan kondisi pengaturan sinyal maupun tanpa pengaturan.
\end{abstract}

\section{Kata Kunci}

Tundaan, Petugas Tidak Resmi, VISSIM

\section{PENDAHULUAN}

Terdapat berbagai macam pengaturan untuk simpang tidak bersinyal, pada umumnya yang sering digunakan adalah dengan penyediaan fasilitas Alat Pemberi Isyarat Lalu-lintas (APILL). Penyediaan fasilitas APILL yang tidak mempertimbangkan kondisi geometrik eksisting akan menyebabkan fasilitas tersebut tidak berfungsi secara optimal. Selain penyediaan APILL, pengaturan simpang dapat dilakukan dengan pemasangan rambu beri jalan (YIELD), rambu stop, bundaran, dan juga pengaturan dengan petugas. Pada kota-kota besar di Indonesia terdapat fenomena munculnya Petugas Tidak Resmi (PTR) atau pak ogah yang mengatur kelancaran arus lalu lintas secara tidak resmi yang biasa ditemui pada persimpangan rel kereta api , persimpangan jalan, serta di putaran jalan. Berbeda dengan petugas resmi dari instansi pemerintahan, petugas tidak resmi ini berasal dari penduduk sekitar daerah persimpangan. Fenomena ini dapat berpengaruh terhadap kinerja suatu persimpangan tidak bersinyal karena petugas tidak resmi ini mengatur arus lalu lintas tidak sesuai dengan peraturan yang berlaku.

Fenomena munculnya PTR ini terdapat pada salah satu simpang tidak bersinyal di Sleman, yakni simpang Kronggahan. Pada simpang tersebut sebelumnya terdapat APILL, namun pemasangannya tidak dapat dimaksimalkan karena kondisi geometrik simpang yang sempit. Sedangkan dilihat dari kendaraan yang lewat sering dilewati kendaraan berat dengan panjang mencapai 7 sampai 12 meter sehingga ketika lampu hijau menyala hanya sedikit kendaraan yang dapat keluar dari simpang sehingga terjadi kemacetan. Penambahan radius tikungan atau pelebaran geometrik simpang dapat dilakukan dengan memotong pojok simpangan, namun terkendala pembebasan lahan yang merupakan pemukiman warga.

Penelitan terdahulu telah dilakukan dengan meneliti Pengaruh Petugas Resmi dan Petugas Tidak Resmi

Perbandingan Kinerja Simpang dengan Pengaturan Petugas Tidak Resmi

Tanpa Pengaturan, dan Pengaturan Siny al, (Studi Kasus Simpang Kronggahan Sleman)

Prima J.Romadona dan Aprijal Yuliansy ah 
Terhadap Lalu Lintas di Persimpangan Prioritas (Studi Kasus Simpamg Kompas Kabupaten Bekasi)[1]. Disimpulkan bahwa tingkat pelayanan simpang terbaik yaitu pada saat simpang dengan kondisi pengaturan oleh petugas resmi (PRE) dengan tundaan 25,8 det/kend. Sedangkan kondisi simpang tanpa pengaturan 30,1 det/kend, dan kondisi simpang dengan PTR 27,03 det/kend. Hasil perhitungan tundaan menyatakan PRE lebih konsisten dalam mengatur arus lalu lintas di persimpangan dengan nilai $R$ square 0,78 . Nilai tersebut lebih besar dari kinerja PTR yaitu 0,52 dan kondisi tanpa pengatur (NON) dengan nilai R square 0,21 .

Studi Konflik Lalu Lintas Sebagai Alat Mengevaluasi Pengaturan Lalu Lintas (Studi Kasus Satu Simpang-T di Kota Bandung) menunjukkan bahwa jumlah konflik serius dan ringan secara signifikan tidak dipengaruhi oleh adanya PTR[2]. Dari kategori konflik, jumlah konflik terbanyak yaitu konflik sama arah pergerakan yang akan belok kanan, konflik menghindar pada lajur yang sama karena kendaraan akan belok kanan, konflik kendaraan pada arah sebaliknya yang menghindari kendaraan akan belok kanan.

Penggunaan Software VISSIM Untuk Analisis Simpang Bersinyal (Studi kasus Simpang Mirota Kampus Terban Yogyakarta)[3]. dihasilkan panjang antrian rata-rata di lapangan dan pemodelan atau simulasi dengan software vis sim hampir sama, yaitu $60 \mathrm{~m}$ dan $61 \mathrm{~m}$. Diketahui juga bahwa terdapat perbedaan yang cukup jauh pada antrian terpanjang dan terpendek yang terjadi berdasarkan pengamatan langsung dan simulasi menggunakan software VISSIM, yaitu $76 \mathrm{~m}$ dan $64 \mathrm{~m}$ untuk antrian terpanjang dan $39 \mathrm{~m}$ dan $51 \mathrm{~m}$ untuk antrian terpendek. Perbedaan ini terjadi karena adanya perbedaan penyebaran antrian antara realita di lapangan dengan simulasi VISSIM.

Pemodelan Simpang Tak Bersinyal Menjadi Simpang Bersinyal Menggunakan Software VISSIM pernah dilakukan di Persimpangan Jalan Kebon Agung, Jalan Gajah Mada, dan Jalan Purbaya, Pasar Cebongan, Sleman, Yogyakarta[4]. Hasil pemodelan pada kondisi eksisting didapatkan panjang antrian rata-rata sebesar 14,75 $\mathrm{m}$, panjang antrian maksimum 161,7 m, dan tingkat pelayanan jalan adalah LOS C. Pemodelan dengan pemberian APILL dibuat menjadi 3 skenario yaitu model simpang bersinyal tanpa LTOR dengan hasil panjang antrian rata-rata $49,27 \mathrm{~m}$, panjang antrian maksimum $153,7 \mathrm{~m}$, dan tingkat pelayanan jalan
LOS E. Model simpang bersinyal dengan LTOR didapatkan hasil panjang antrian rata-rata sebesar $37,36 \mathrm{~m}$, panjang antrian maksimum sebesar 151,07 $\mathrm{m}$, denhan tingkat pelayanan jalan adalah LOS E dan model simpang bersinyal dengan LTOR dan pelebaran jalan sebesar 1,5 m pada lengan utara dan selatan skenario yang dipilih untuk mengurangi crossing dengan hasil simulasi panjang antrian ratarata sebesar $34,39 \mathrm{~m}$, panjang antrian maksimum sebesar 152,82 $\mathrm{m}$ dan tingkat pelayanan jalan adalah LOS D.

Analis is Pengaruh Kinerja Lalu Lintas Terhadap Pemasangan Traffic Light Pada Simpang Tiga (Studi kasus Simpang KKA) diperoleh derajat kejenuhan pada pendekat A (Medan - Banda Aceh) sebesar 0,74, pendekat B (Sp. KKA - Keluar) 0,32 dan pendekat C (Banda Aceh - Medan) 0,72 yaitu tergolong dalam kondisi stabil, artinya kapasitas simpang masih sanggup menampung arus maksimum yang melewati persimpangan tersebut, untuk nilai tundaan rata-rata seluruh simpang diperoleh hasil 7,60 det/smp sesuai dengan tabel tundaan simpang rata-rata (LOS) maka tingkat pelayanan yang diperoleh adalah B (baik)[5].

\section{LANDASAN TEORI}

\subsection{Tundaan}

Tundaan adalah waktu yang hilang akibat adanya gangguan lalu lintas yang terjadi sehingga menambah waktu tempuh selama dalam perjalanan. Tundaan pada suatu simpang dapat terjadi karena dua hal, yaitu.

1. Tundaan lalu lintas (DT) karena interaksi lalu lintas dengan gerakan lainnya pada suatu simpang.

2. Tundaan geometri (DG) karena perlambatan dan percepatan saat membelok pada suatu simpang dan atau terhenti karena lampu merah[6].

Jika kendaraan berhenti terjadi antrian di persimpangan sampai kendaraan tersebut keluar dari persimpangan karena adanya pengaruh kapasitas persimpangan yang sudah tidak memadai. Semakin tinggi nilai tundaan maka semakin tinggi juga waktu tempuhnya[7].

\subsection{Kinerja Persimpangan}

Kinerja atau tingkat pelayanan adalah suatu ukuran yang digunakan untuk mengetahui kualitas suatu ruas jalan atau persimpangan jalan tertentu dalam melayani arus lalu lintas yang melewatinya. Hubungan antara kecepatan dan volume jalan perlu 
diketahui karena kecepatan dan volume merupakan aspek penting dalam menentukan tingkat pelayanan kecepatan konstan, maka pengemudi akan mengalami kelelahan dan tidak dapat memenuhi waktu perjalanan yang direncanakan.

Tingkat pelayanan adalah ukuran kecepatan laju kendaraan yang dikaitkan dengan kondisi dan kapasitas jalan[8].Terdapat beberapa indikator yang harus dipenuhi dalam menentukan tingkat pelayanan, antara lain[9].

1. Rasio antara volume dan kapasitas jalan.

2. kecepatan yang merupakan kecepatan batas atas dan batas bawah yang ditetapkan berdasarkan kondisi daerah.

3. Waktu perjalanan.

4. Kebebasan bergerak.

5. Keamanan.

6. Keselamatan.

7. Ketertiban.

8. Kelancaran.

9. Penilaian pengemudi terhadap kondisi arus lalu lintas.

Tabel 1. Kriteria tingkat pelayanan pada simpang

\begin{tabular}{ccc}
\hline No & $\begin{array}{c}\text { Tundaan per kend } \\
(\text { det/kend })\end{array}$ & $\begin{array}{c}\text { Tingkat } \\
\text { Pelayanan }\end{array}$ \\
\hline 1 & $<5$ & A \\
\hline 2 & $5,1-15$ & B \\
\hline 3 & $15,1-25$ & $\mathrm{C}$ \\
\hline 4 & $25,1-40$ & $\mathrm{D}$ \\
\hline 5 & $40,1-60$ & $\mathrm{E}$ \\
\hline 6 & $>60$ & $\mathrm{~F}$ \\
\hline
\end{tabular}

Sumber : [9]

\subsection{Petugas Pengatur Lalu Lintas}

Petugas pengatur lalu lintas merupakan seseorang yang berhak dan mempunyai peranan untuk mengatur lalu lintas demi tercapainya kelancaran, keamanan, keselamatan, dan juga ketertiban berlalu lintas. Di Indonesia terdapat dua lembaga resmi yang berperan dalam mengatur jalannya lalu lintas yaitu Polantas (Polisi Lalu Lintas) dan juga petugas Dinas Perhubungan yang mempunyai peranannya masing-masing dalam mengatur kelancaran lalu lintas di jalan. Petugas pengatur lalu lintas ini telah diatur secara legal dalam peraturan [10],Serta dalam undang-undang [11].

Petugas pengatur lalu lintas tidak resmi atau PTR merupakan masyarakat atau warga biasa yang jalan. Apabila volume lalu lintas pada suatu jalan meningkat dan tidak dapat mempertahankan suatu bekerja sebagai pengatur lalu lintas yang tidak memiliki wewenang maupun ilmu dibidangnya sebagai petugas pengatur lalu lintas. Berikut merupakan beberapa kerugian yang ditimbulkan oleh petugas tidak resmi atau PTR[2].

1. Mengutamakan kendaraan yang memberikan tip besar untuk melintasi simpang.

2. Mematahkan arus kendaraan di jalan utama walaupun antrian akibat pematahan arus sebelumnya belum habis .

3. Mematahkan arus lalu lintas di jalan utama jika antrian kendaraan di jalan minor telah panjang.

\subsection{Alat Pemberi Isyarat Lalu Lintas}

Alat Pemberi Isyarat Lalu Lintas (APILL), adalah perangkat peralatan teknis yang menggunakan is yarat lampu untuk mengatur lalu lintas orang dan atau kendaraan di persimpangan atau ruas jalan [12].

Alasan dipergunakannya sinyal lalu lintas pada persimpangan adalah sebagai berikut [6].

1. Untuk menghindari kemacetan simpang akibat adanya konflik arus lalu lintas sehingga terjamin bahwa suatu kapasitas tertentu dapat dipertahankan, bahkan selama kondisi lalu lintas jam puncak.

2. Untuk memberi kesempatan kepada kendaraan dan atau pejalan kaki dari jalan simpang (kecil) untuk memotong jalan utama.

3. Untuk mengurangi jumlah kecelakaan lalu lintas akibat tabrakan antara kendaraan dari arah yang berlawanan.

Pengaturan persimpangan dilihat dari segi pandang untuk kontrol kendaraan dapat dibedakan menjadi dua, antara lain sebagai berikut[13].

1. Persimpangan tanpa sinyal, dimana pengemudi kendaraan sendiri yang harus memutuskan apakah aman untuk memasuki persimpangan itu.

2. Persimpangan dengan sinyal, dimanapersimpangan itu diatur sesuai sistem dengan tiga aspek lampu yaitu merah, kuning, dan hijau.

Sasaran yang harus dicapai pada pengendalian persimpangan antara lain adalah[14].

1. Mengurangi atau menghindari kemungkinan terjadinya kecelakaan yang disebabkan oleh adanya titik-titik konflik seperti : Berpencar (diverging), bergabung (merging), berpotongan (crossing), dan bersilangan (weaving).

2. Menjaga agar kapasitas persimpangan operasinya dapat optimal sesuai dengan rencana.

Perbandingan Kinerja Simpang dengan Pengaturan Petugas Tidak Resmi

Tanpa Pengaturan, dan Pengaturan Sinyal, (Studi Kasus Simpang Kronggahan Sleman)

Prima J.Romadona dan Aprijal Yuliansy ah 
3. Harus memberikan petunjuk yang jelas dan pasti serta sederhana, dalam mengarahkan arus lalu lintas yang menggunakan persimpangan.

\subsection{Analisis Waktu Siklus Simpang}

Untuk perhitungan arus lalu lintas digunakan satuan smp/jam yang dibagi dalam dua tipe yaitu arus terlindung dan terlawan, yang tergantung pada fase sinyal dan gerakan belok kanan. Penentuan nilai ekivalensi mobil penumpang adalah sebagai berikut[6].

Tabel 2. Nilai ekivalensi satuan mobil penumpang

\begin{tabular}{ccc}
\hline & \multicolumn{2}{c}{ Emp } \\
\cline { 2 - 3 } Tipe kendaraan & $\begin{array}{c}\text { Pendekat } \\
\text { terlindung }\end{array}$ & $\begin{array}{c}\text { Pendekat } \\
\text { terlawan }\end{array}$ \\
\hline LV & 1 & 1 \\
\hline HV & 1,3 & 1,3 \\
\hline MC & 0,2 & 0,4 \\
\hline
\end{tabular}

Sumber: [6]

1. Arus jenuh dasar $\left(\mathrm{S}_{0}\right)$

Arus jenuh dasar $\left(\mathrm{S}_{0}\right)$ adalah besarnya keberangkatan antrian di dalam pendekat selama kondisi edeal (smp/jam hijau). Perhitungan nilai arus jenuh dasar yang merupakan pengalian nilai konstanta dengan lebar lajur.Dari penelitian yang telah dilakukan didapatkan nilai arus jenuh yang ada di lapangan lebih besar 1,3 kali, sehingga rumus empiris dari MKJI 1997 tersebut dianjurkan untuk dikoreksi[15]. Arus jenuh dasar dihitung menggunakan persamaan 1 berikut:

$\mathrm{S}_{0}=780 \times \mathrm{W}_{\mathrm{e}}$

Keterangan :

$\mathrm{S}_{0}=$ Arus jenuh dasar (smp/jam hijau)

$\mathrm{W}_{\mathrm{e}}=$ Lebar pendekat $(\mathrm{m})$

2. Waktu Hijau $\left(g_{i}\right)$

Waktu hijau untuk masing-masing fase dapat dihitung menggunakan persamaan 2 berikut:

$\mathrm{g}_{\mathrm{i}}=\mathrm{C}_{\mathrm{ua}}-\mathrm{LTI} \times \mathrm{PR}_{\mathrm{i}}$

Keterangan :

gi = Tampilan waktu hijau pada fase i (detik)

$\mathrm{C}_{\mathrm{ua}}=\mathrm{Waktu}$ siklus sebelum penyesuaian

(detik)

LTI = Waktu hilang total per siklus (detik)

$\mathrm{PR}_{\mathrm{i}}=$ Rasio fase $\mathrm{FR}_{\text {crit }} / \mathrm{FR}_{\text {crit }}$
3. Waktu siklus (C)

Waktu siklus yang telah disesuaikan dihitung berdasarkan pada waktu hijau yang diperoleh dan waktu hilang. Perhitungan waktu siklus menggunakan persamaan 3 sebagai berikut:

$\mathrm{C}=\sum \mathrm{g}+\mathrm{LTI}$

Keterangan :

$\mathrm{C}$ = Waktu hijau yang disesuaikan (detik)

$\mathrm{g} \quad=$ Waktu hijau (detik)

LTI = Waktu hilang total per siklus (detik)

Tabel 3.Nilai Waktu Siklus Yang Disarankan Berdasarkan Pengaturan Fase

Tipe pengaturan Waktu siklus yang layak (det)

\begin{tabular}{ll}
\hline Pengaturan dua fase & $40-80$ \\
\hline Pengaturan tiga fase & $50-100$ \\
\hline Pengaturan empat fase & $80-130$ \\
\hline Sumber: [6] &
\end{tabular}

\subsection{Analisis Menggunakan Program VISSIM}

Program VISSIM (Verkehr in Stadten Simulationsmodel) merupakan program simulasi mikroskopis untuk pemodelan transportasi multimedia operasi yang dimiliki oleh Vision Traffic Suite Software[16].VISSIM adalah aplikasi mikroskopis, berorientasi waktu, dan alat simulasi berbasis perilaku untuk pemodelan lalu lintas perkotaan dan pedesaan serta arus pejalan kaki. Program ini dapat menganalis is pengerjaan privat maupun transportasi publik dibawah kendala seperti konfigurasi jalur, komposisi kendaraan, sinyal lalu lintas, dan lain-lain sehingga membuat program ini menjadi bermanfaat untuk mengevaluasi berbagai macam efektifitas. VISSIM dapat dipakai untuk berbagai macam variasi problem pada transportasi.

\section{METODE PENELITIAN}

\subsection{Lokasi Penelitian}

Lokasi penelitian terletak di simpang Kronggahan, jalan Kabupaten, Kabupaten Sleman, Yogyakarta. 


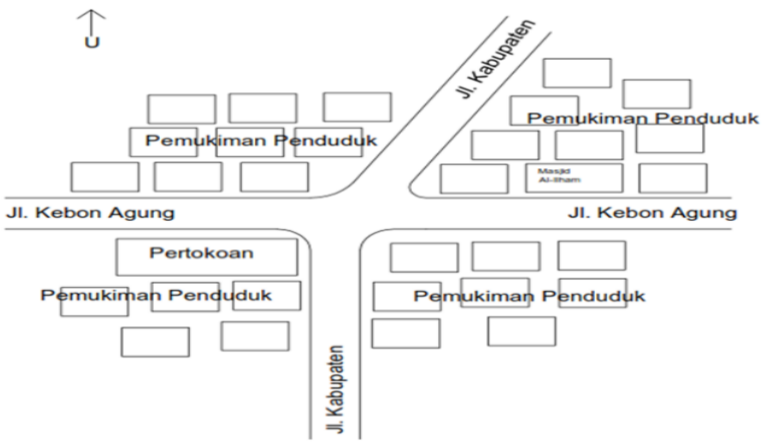

Gambar 1 Lokasi penelitian

\subsection{Waktu Penelitian}

Waktu penelitian ini dilaksanakan selama 4 hari, yaitu 2 hari pada saat kondisi simpang dengan pengaturan oleh Petugas Tidak Resmi (PTR) dan 2 hari pada saat kondisi simpang tanpa pengaturan. Survei dilakukan pada hari kerja serta hari libur atau akhir pekan. Berikut merupakan waktu pengambilan data.

1. Pagi $=07.00-10.00$ WIB.

2. Sore $=15.00-18.00$ WIB.

Penetapan waktu pelaksanaan survei berdasarkan pertimbangan bahwa survei dapat mewakili hari kerja (normal) dan hari libur serta pada jam-jam sibuk (ramai kendaraan).

\subsection{Pengumpulan Data}

Data primer diperoleh dengan cara melakukan pengamatan langsung di lapangan yang meliputi kondisi geometri jalan, kondisi lingkungan jalan, arus lalu lintas, kecepatan kendaraan, dan driving behaviour. Driving behaviour merupakan data jarak antar kandaraan berdampingan maupun depanbelakang pada saat kendaraan berjalan dan berhenti, yang kemudian digunakan sebagai parameter proses validasi pemodelan VISSIM.

Data sekunder yang dibutuhkan dalam mengerjakan penelitian ini adalah jumlah penduduk Kabupaten Sleman Provinsi Yogyakarta tahun 2017[17].

\section{ANALISIS}

Dari data volume lalu lintas didapat periode jam puncak untuk kondisi simpang dengan dan tanpa PTR terjadi pada periode hari kerja. Untuk kondisi simpang dengan PTR, jam puncak terjadi pada hari senin 19 Februari 2018 pukul 07.00 - 08.00 WIB dengan volume kendaraan 6543 kend/jam. Sedangkan kondisi simpang tanpa PTR didapatkan jam puncak pada hari selasa 20 Februari 2018 pukul 07.00 - 08.00 WIB dengan volume kendaraan 6315 kend/jam. Berikut merupakan data distribusi pergerakan arus lalu lintas per-arah pada periode jam puncak.

Analisis data pada penelitian ini menggunakan metode berdasarkan Direktorat Jenderal Bina Marga 1997 (MKJI 1997) untuk menentukan waktu siklus simpang empat dan menggunakan program VISSIMuntuk pemodelan simpang dalam beberapa kondisi yaitu simpang tidak bersinyal, simpang bersinyal, dan simpang dengan pengaturan petugas tidak resmi.

\subsection{Waktu Siklus Simpang}

Waktu siklus yang disesuaikan (c) diperoleh dari penjumlahan waktu hijau pada tiap fasenya ditambah dengan waktu hilang (LTI).

$c=(21+17+31+47)+16=132$ detik

Waktu siklus untuk pengaturan 4 fase maksimal adalah 130 detik[6].Waktu siklus simpang dapat diambil lebih dari 130 detik pada kondisi kota-kota besar dengan kamcetan tinggi[15]. Maka waktu siklus yang dipakai adalah sebesar 150 detik. Berikut nilai waktu hijau untuk masing-masing lengan dengan waktu siklus 150 detik.

Lengan utara $\quad=29$ detik

Lengan timur $\quad=34$ detik

Lengan selatan $\quad=31$ detik

Lengan barat $\quad=40$ detik

$c=(29+34+31+40)+16=150$ detik

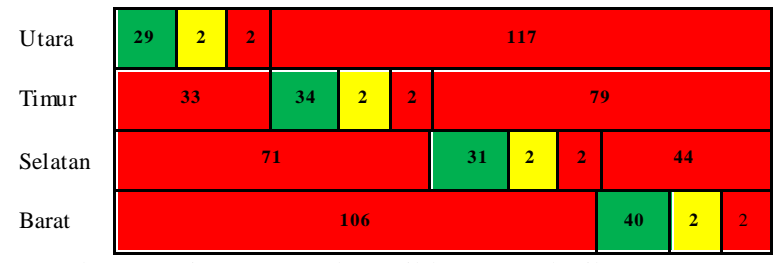

Gambar 2 Diagram waktu siklus 150 detik

\section{HASIL DAN PEMBAHASAN}

\subsection{Hasil Analisis Pemodelan Program VISSIM}

Pemodelan menggunakan program VISSIMharus melewati proses kalibrasi dan validasi. Proses kalibrasi merupakan proses penyesuaian komponen model simulasi sesuai dengan kondisi di lapangan. Sedangkan proses validasi merupakan proses perbandingan parameter volume hasil dari output VISSIMdengan volume di lapangan. Hasil pemodelan VISSIMdapat dikatakan valid jika perbandingan volume hasil output dan lapangan tidak melebihi 15\%[18]. Berikut hasil validasi volume dari pemodelan VISSIM. 
Tabel 4. Hasil Validasi Volume Kondisi Simpang Tanpa Pengaturan

\begin{tabular}{|c|c|c|c|c|}
\hline Lengan & $\begin{array}{c}\text { Volume } \\
\text { Eksisting } \\
\text { (kend/jam) }\end{array}$ & $\begin{array}{l}\text { Volume Hasil } \\
\text { VISSIM } \\
\text { (kend/jam) }\end{array}$ & $\begin{array}{c}\text { Selisih } \\
\text { (kend/jam) }\end{array}$ & $\begin{array}{c}\text { Persentase } \\
(\%)\end{array}$ \\
\hline Utara & 852 & 811 & 41 & 4,812 \\
\hline Timur & 1021 & 988 & 33 & 3,232 \\
\hline Selatan & 1333 & 1249 & 84 & 6,302 \\
\hline Barat & 3109 & 2948 & 161 & 5,179 \\
\hline Lengan & $\begin{array}{c}\text { Volume } \\
\text { Eksisting } \\
\text { (kend/jam) }\end{array}$ & $\begin{array}{c}\text { Volume Hasil } \\
\text { VISSIM } \\
\text { (kend/jam) }\end{array}$ & $\begin{array}{c}\text { Selisih } \\
\text { (kend/jam) }\end{array}$ & $\begin{array}{c}\text { Persentase } \\
(\%)\end{array}$ \\
\hline Selatan & 1357 & 1367 & 7 & 0,737 \\
\hline Barat & 2993 & 2821 & 172 & 5,773 \\
\hline
\end{tabular}

Tabel 6. Hasil Validasi Volume Kondisi S impang Pengaturan Sinyal Siklus 150 detik

\begin{tabular}{|c|c|c|c|c|}
\hline Lengan & $\begin{array}{c}\text { Volume } \\
\text { Eksisting } \\
\text { (kend/jam) }\end{array}$ & $\begin{array}{l}\text { Volume Hasil } \\
\text { VISSIM } \\
\text { (kend/jam) }\end{array}$ & $\begin{array}{c}\text { Selisih } \\
(\mathrm{kend} / \mathrm{j} \\
\mathrm{am})\end{array}$ & $\begin{array}{c}\text { Persentase } \\
(\%)\end{array}$ \\
\hline Utara & 852 & 799 & 53 & 6,221 \\
\hline Timur & 1021 & 972 & 49 & 4,799 \\
\hline Selatan & 1333 & 1272 & 61 & 4,576 \\
\hline Barat & 3109 & 2863 & 246 & 7,913 \\
\hline
\end{tabular}

Berikut ini merupakan hasil tundaan dan panjang antrian dari analis is pemodelan program VISSIM.

Tabel 7. Tundaan dan Panjang Antrian Kondisi Simpang Tanpa Pengaturan

\begin{tabular}{|c|c|c|}
\hline Lengan & $\begin{array}{c}\text { VehDelay (all) } \\
\text { (detik) }\end{array}$ & $\begin{array}{c}\text { Qlen } \\
\text { (meter) }\end{array}$ \\
\hline Utara & 38,31 & 66,23 \\
\hline Timur & 16,74 & 18,19 \\
\hline Selatan & 47,23 & 224,35 \\
\hline Barat & 10,44 & 142,61 \\
\hline
\end{tabular}

Tabel 8. Tundaan dan Panjang Antrian Kondisi Simpang Pengaturan PTR

\begin{tabular}{ccc}
\hline Lengan & $\begin{array}{c}\text { Veh Delay (all) } \\
\text { (detik) }\end{array}$ & $\begin{array}{c}\text { Qlen } \\
\text { (meter) }\end{array}$ \\
\hline Utara & 9,86 & 11,65 \\
\hline Timur & 3,31 & 1,74 \\
\hline Selatan & 3,07 & 5,95 \\
\hline Barat & 12,57 & 182,12 \\
\hline
\end{tabular}

Tabel 5. Hasil Validasi Volume Kondisi Simpang Pengaturan PTR

\begin{tabular}{ccccc}
\hline Lengan & $\begin{array}{c}\text { Volume } \\
\text { Eksisting } \\
\text { (kend/jam) }\end{array}$ & $\begin{array}{c}\text { Volume } \\
\text { Hasil } \\
\text { VISSIM } \\
\text { (kend/jam) }\end{array}$ & Selisih & Persentase \\
(kend/jam) & $(\%)$ \\
\hline Utara & 1154 & 1137 & 17 & 1,508 \\
\hline Timur & 1039 & 1014 & 25 & 2,406 \\
\hline
\end{tabular}

Tabel 9. Tundaan dan Panjang Antrian Kondisi Simpang Pengaturan Sinyal 150 detik

\begin{tabular}{|c|c|c|}
\hline Lengan & $\begin{array}{c}\text { Veh Delay (all) } \\
\text { (detik) }\end{array}$ & $\begin{array}{l}\text { Qlen } \\
\text { (meter) }\end{array}$ \\
\hline Utara & 38,453 & 54,827 \\
\hline Timur & 38,577 & 26,541 \\
\hline Selatan & 37,207 & 204,861 \\
\hline Barat & 28,698 & 276,31 \\
\hline
\end{tabular}

\subsection{Pembahasan}

Berdasarkan analisis pemodelan menggunakan program VISSIM didapatkan hasil berupa nilai tundaan yang terjadi pada simpang Kronggahan dalam tiga jenis kondisi yakni kondisi simpang tanpa pengaturan, simpang dengan pengaturan sinyal, dan simpang dengan pengaturan Petugas Tidak Resmi (PTR). Penetapan tingkat pelayanan simpang menurut peraturan yaitu berdasarkan nilai tundaan yang terjadi pada simpang[9]. Dari hasil analisis menggunakan program VISSIMyang didapatkan nilai tundaan dengan simpang kondisi tanpa pengaturan untuk lengan utara sebesar 38,31 detik dengan LOS D, lengan timur 16,74 detik dengan LOS C, lengan selatan 47,23 detik dengan LOS E, dan lengan barat 10,44 detik dengan LOS B. Pada saat kondisi simpang diberi pengaturan sinyal terjadi kenaikan nilai tundaan pada lengan timur dan barat sebesar $130 \%$ dan $175 \%$, sedangkan pada lengan selatan mengalami penurunan sebesar 21\%.Kondisi simpang dengan pengaturan PTR mengalami penurunan nilai tundaan pada masingmasing lengannya lebih dari 50\%, namun pada lengan barat mengalami kenaikan nilai tundaan sebesar 20\% dibandingkan dengan kondisi simpang tanpa pengaturan.

Perbandingan Kinerja Simpang dengan Pengaturan Petugas Tidak Resmi

Tanpa Pengaturan, dan Pengaturan Siny al, (Studi Kasus Simpang Kronggahan Sleman)

Prima J.Romadona dan Aprijal Yuliansy ah 
Kondisi simpang tanpa pengaturan didapatkan tundaan terpanjang terjadi pada lengan selatan yakni sebesar 224,346 meter. Pada saat diberi sinyal, nilai panjang antrian mengalami penurunan sebesar $10 \%$ dan panjang antrian terbesar terjadi pada lengan barat yakni 276,310 meter. Pada kondisi simpang dengan pengaturan PTR panjang antrian terbesar terjadi pada lengan barat sebesar 182,117 meter, sedangkan pada lengan lainnya mengalami penurunan yang cukup banyak yakni lebih 50\% dibandingkan dengan kondisi tanpa pengaturan maupun dengan pengaturan sinyal.

Kondisi simpang dengan pengaturan PTR memiliki tingkat pelayanan yang lebih baik dibandingan dengan kondisi simpang dengan pengaturan sinyal maupun tanpa pengaturan. Dibandingkan dengan pengaturan sinyal, pengaturan PTR lebih baik dari segi tundaannya karena pengaturan PTR tidak terdapat waktu hilang (LTI). Jika dibandingkan dengan simpang tanpa pengaturan, PTR dapat mengatur lalu lintas secara langsung menyesuaikan dengan arus lalu lintas yang melewati simpang.

Tabel 10. Perbandingan Tingkat Pelayanan Simpang

\begin{tabular}{|c|c|c|c|c|c|c|c|c|}
\hline \multirow[b]{2}{*}{ Lengan } & \multicolumn{2}{|c|}{ Tanpa Pengaturan } & \multicolumn{2}{|c|}{ Dengan Sinyal } & \multicolumn{4}{|c|}{ Dengan PTR } \\
\hline & $\begin{array}{c}\text { Tundaan } \\
\text { (det) }\end{array}$ & LOS & $\begin{array}{c}\text { Tundaan } \\
\text { (det) }\end{array}$ & $\begin{array}{c}\text { Perbedaan } \\
(\%)\end{array}$ & LOS & $\begin{array}{c}\text { Tundaan } \\
\text { (det) }\end{array}$ & $\begin{array}{c}\text { Perbedaan } \\
(\%)\end{array}$ & LOS \\
\hline Utara & 38,31 & $\mathrm{D}$ & 38,45 & $-0,38$ & $\mathrm{D}$ & 9,86 & 74 & $\mathrm{~B}$ \\
\hline Timur & 16,74 & $\mathrm{C}$ & 38,58 & -130 & $\mathrm{E}$ & 3,31 & 80 & A \\
\hline Selatan & 47,23 & $\mathrm{E}$ & 37,21 & 21 & $\mathrm{D}$ & 3,07 & 94 & A \\
\hline Barat & 10,44 & B & 28,7 & -175 & $\mathrm{D}$ & 12,57 & -20 & B \\
\hline
\end{tabular}

\section{KESIMPULAN DAN SARAN}

\subsection{Kesimpulan}

Berdasarkan hasil survei dan analisis pengaruh pengaturan Petugas Tidak Resmi (PTR) terhadap kinerja simpang empat tidak bersinyal menggunakan pemodelan program VISSIM dapat disimpulkan beberapa hal sebagai berikut:

1. Kondisi simpang Kronggahan pada saat tidak terdapat pengaturan, baik dengan sinyal maupun dengan Petugas Tidak Resmi (PTR) didapatkan nilaitundaan yaitu pada arah Utara 38,308 detik, arah Timur 16,737 detik, arah Selatan 47,228 detik, dan arah Barat 10,437 detik. Nilai panjang antrian pada arah Utara sebesar 66,232 meter, arah Timur sebesar 18,188 meter, arah Selatan sebesar 224,346 meter, dan arah Barat sebesar 142, 610 meter. Berdasarkan Peraturan Menteri Perhubungan Nomor PM 96 Tahun 2015, tingkat pelayanan simpang ditentukan berdasarkan tundaan yang terjadi, sehingga kinerja simpang Kronggahan pada kondisi tanpa pengaturan didapat nilai kinerja (Level Of Service) untuk lengan Utara adalah D, lengan Timur adalah C, lengan Selatan adalah E, dan lengan Barat adalah B.

2. Kondisi simpang Kronggahan pada saat diberi pengaturan sinyal didapatkan nilai tundaan pada arah Utara 38,45 detik, arah Timur 38,58 detik, arah Selatan 37,21 detik, dan arah Barat 28,70 detik. Nilai panjang antrian pada arah utara sebesar 54,83 meter, arah Timur 26,54 meter, arah Selatan 204,86 meter, dan arah Barat 276,31 meter. Berdasarkan Peraturan Menteri Perhubungan Nomor PM 96 Tahun 2015, tingkat pelayanan simpang ditentukan berdasarkan tundaan yang terjadi, sehingga kinerja simpang Kronggahan pada kondisi tanpa pengaturan didapat nilai kinerja (Level Of Service) untuk lengan Utara adalah D, lengan Timur adalah D, lengan Selatan adalah D, dan lengan Barat adalah D.

3. Kondisi simpang Kronggahan pada saat diatur oleh Petugas Tidak Resmi (PTR) didapatkan nilai tundaan untuk arah utara 9,856 detik, arah Timur 3,311 detik, arah Selatan 3,066 detik, dan arah Barat 12,574 detik. Nilai panjang antrian pada arah Utara 11,649 meter, arah Timur 1,737 
meter, arah Selatan 5,951 meter, dan arah Barat 182,118 meter. Berdasarkan Peraturan Menteri Perhubungan Nomor PM 96 Tahun 2015, tingkat pelayanan simpang ditentukan berdasarkan tundaan yang terjadi, sehingga kinerja simpang Kronggahan pada kondisi tanpa pengaturan didapat nilai kinerja (Level Of Service) untuk lengan Utara adalah B, lengan Timur adalah A, lengan Selatan adalah A, dan lengan Barat adalah B.

4. Terdapat perbedaan yang cukup signifikan terhadap tiga kondisi pemodelan simpang Kronggahan tersebut. Hasil analisis menunjukkan bahwa pada kondisi simpang tanpa pengaturan terjadi tundaan yang cukup tinggi pada lengan utara dan lengan selatan yakni 38,31 detik dan 47,23 detik. Pada saat simpang diberi kontrol sinyal terjadi penurunan nilai tundaan pada lengan utara sebesar 3\% dan lengan selatan sebesar $27 \%$, namun pada lengan timur dan lengan barat mengalami kenaikan nilai tundaan lebih dari $100 \%$. Tingkat pelayanan atau kinerja simpang terbaik yaitu pada saat simpang diatur oleh petugas tidak resmi karena mengalami penurunan nilai tundaan lebih dari $50 \%$ pada tiap lengannya dibandingan dengan kondisi eksisting maupun kondisi diberi pengaturan sinyal.

\subsection{Saran}

Setelah melakukan pengamatan langsung dan juga analisis, berikut merupakan saran yang dapat diajukan untuk melakukan penelitian selanjutnya.

1. Untuk memperoleh hasil yang dapat mewakili pengaruh pengaturan Petugas Tidak Resmi (PTR) terhadap suatu persimpangan, perlu dilakukan penelitian pada beberapa simpang yang diatur oleh Petugas Tidak Resmi (PTR).

2. Mengukur tundaan dan panjang antrian secara langsung di lapangan pada saat kondisi simpang dengan pengaturan Petugas Tidak Resmi (PTR) dan membandingkan dengan hasil analisis menggunakan program VISSIM.

\section{DAFTAR PUSTAKA}

[1] Al Qadri, M. 2006. Pengaruh Petugas Resmi Dan Petugas Tidak Resmi Terhadap Lalu Lintas Di Persimpangan Prioritas : Studi Kasus Simpang Kompas Kabupaten Bekasi. Tesis. (Tidak Diterbitkan). Universitas Gadjah Mada. Yogyakarta.
[2] Lawalata, G.M. 2010. Studi Konflik Lalu Lintas Sebagai Alat Mengevaluasi Pengaturan Lalu Lintas : Studi Kasus Satu Simpang-T Di Kota Bandung. Pusat Litbang Jalan Dan Jembatan. Bandung.

[3] Aryandi, R.D. 2014. Penggunaan Software Vissim Untuk Analisis Simpang Bersinyal : Studi Kasus Simpang Mirota Kampus Terban Yogy akarta.Prosiding The $17^{\text {th }}$ FSTPT International Symposium. Jember University. 22-24 Agustus.

[4] Fauzy, M.A., Widodo, W., dan Muchlisin. 2017. Pemodelan Simpang Tak Bersinyal Menjadi Simpang Bersinyal Menggunakan Software VISSIM.Tugas Akhir. Universitas Muhammadiyah. Yogy akarta.

[5] Anggraini, L., Hamzani, dan Zulfhazli. 2015. Analisis Pengaruh Kinerja Lalu Lintas Terhadap Pemasangan Traffic Light Pada Simpang Tiga : Studi Kasus Simpang KKA. Teras Jurnal. Vol.5 No.2:ISSN 2088-0561. Aceh.

[6] Direktorat Jenderal Bina Marga. 1997. Manual Kapasitas Jalan Indonesia. Bina Karya. Jakarta.

[7] Tamin, O,Z. 2000. Perencanaan dan Pemodelan Transportasi. ITB. Bandung.

[8] Warpani, S. 2002. Pengelolaan Lalu Lintas dan Angkutan Jalan.ITB. Bandung.

[9] Peraturan Menteri Perhubungan Republik Indonesia Nomor PM 96 Tahun 2015. Pedoman Pelaksanaan Manajemen dan Rekayasa Lalu Lintas. Menteri Perhubungan Republik Indonesia. Jakarta.

[10] Peraturan Kepala Kepolisian Negara Republik Indonesia Nomor 10 Tahun 2012. Tentang Pengaturan Lalu Lintas Dalam Keadaan Tertentu Dan Penggunaan Jalan Selain Untuk Kegiatan Lalu Lintas. Kepala Kepolisian Negara Republik Indonesia. Jakarta.

[11] Undang-Undang Republik Indonesia Nomor 22 Tahun 2009. Tentang Lalu Lintas dan Angkutan Jalan. Jakarta.

[12] Keputusan Menteri Perhubungan Nomor KM 62 Tahun 1993. Tentang Alat Pemberi Isyarat Lalu Lintas. Menteri Perhubungan. Jakarta.

[13] Morlok, E. (1991). Pengantar dan Perencanaan Transportasi. Erlangga. Jakarta.

[14] Abubakar, I. 1995. Rekayasa dan Manajemen Lalu Lintas. Direktorat Jenderal Perhubungan Darat. Departemen Perhubungan. Jakarta.

[15] Munawar, A. 2004. Manajemen Lalu Lintas Perkotaan. Beta Offset. Yogy akarta.

[16] PTV-AG. 2016. VISSIM 8 User Manual. PTV. Karlsruhe.

[17] Dinas Kependudukan Provinsi Yogyakarta 2017. (online). Jumlah Penduduk Sleman Menurut Jenis Kelamin

[18] Collins P. 2009. Paramics Microsimulation Modelling-RTA Manual. New South Wales Goverment. USA

Perbandingan Kinerja Simpang dengan Pengaturan Petugas Tidak Resmi

Tanpa Pengaturan, dan Pengaturan Sinyal, (Studi Kasus Simpang Kronggahan Sleman)

Prima J.Romadona dan Aprijal Yuliansy ah 